\title{
After 10 years the myth of Crotalaria spp. and dragonflies remains alive
}

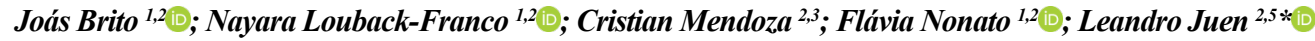 \\ \& Thaisa Michelan ${ }^{1,4}$ (i) \\ ${ }^{1}$ Universidade Federal do Pará/EMBRAPA, Programa de Pós-Graduação em Ecologia, Belém, Pará, Brasil. \\ ${ }^{2}$ Universidade Federal do Pará, Laboratório de Ecologia e Conservação, Belém, PA, Brasil. \\ ${ }^{3}$ Universidade Federal do Pará, Museu Paraense Emílio Goeldi, Programa de Pós-Graduação em Zoologia, Belém, \\ Pará, Brasil. \\ ${ }^{4}$ Universidade Federal do Pará, Laboratório de Ecologia de Produtores Primários, Belém, PA, Brasil. \\ ${ }^{5}$ Universidade Federal do Pará, Instituto de Ciências Biológicas, Belém, PA, Brasil. \\ *Corresponding author: Leandro Juen. Rua Augusto Corrêa, e-mail: leandrojuen@ufpa.br
}

Brito, J.S. Louback-Franco, N. Mendoza, C.C. Nonato, F.A.S. Juen, L. Michelan, T.S. After 10 years the myth of Crotalaria spp. and dragonflies remains alive. Biota Neotropica. 20(2): e20190907. https://doi.org/10.1590/16760611-BN-2019-0907

\begin{abstract}
The struggle to control insect-borne diseases can lead to make rash decisions. For instance, the controversial method of planting of Crotalaria spp. to attract predatory dragonflies can be used to control insect vectors of dengue fever and several other medically significant insect-borne diseases. Nevertheless, there is no scientific support for this assumption. Despite the lack of evidence, in Brazil, there remains a multitude of online articles and grey literature sources still promote Crotalaria planting as a means to prevent dengue fever. Here we discuss the reasons why Odonata would not be attracted by Crotalaria and, therefore, it cannot not be considered as an efficient method for vector control. Finally, the best practice to avoid the spread of insect-borne diseases in the tropics is to avoid the accumulation of standing water in urban areas.
\end{abstract}

Keywords: Mosquitoes, tropical diseases, zika, invasive species.

\section{Após 10 anos, o mito de Crotalaria spp. e libélulas permanece vivo}

Resumo: A luta contra doenças pode levar as pessoas a tomar decisões precipitadas. Um método controverso que estamos discutindo é o da Crotalaria atraindo libélulas, porém nenhuma pesquisa científica apoia essa premissa. As libélulas são predadoras generalistas e, eventualmente, são empregadas de uma maneira incorreta como predadoras de mosquitos vetores. No Brasil, depois de dez anos, ainda encontramos pessoas que estão plantando Crotalaria com a tentativa de evitar a propagação da dengue. Discutimos as razões pelas quais os Odonata não seriam atraídos pela Crotalaria e, portanto, não poderiam ser utilizados como método eficiente de controle de vetores. Por fim, não deixar a água parada é a maneira mais eficaz de evitar doenças tropicais.

Palavras-chave: Mosquitos, doenças tropicais, zika, espécies invasoras. 


\section{A background on Odonata}

The order Odonata (Insecta) (Figure 1), known as the dragonflies and damselflies, is one of the oldest insect groups on the planet (Mitterboeck \& Adamowicz 2013). These insects are very common around the water bodies (e. g. waterfalls, ponds, streams, rivers, and lakes) and play important functional roles in these environments, as both predators of small arthropods, amphibians and fish, and prey items for larger vertebrate predators (Miguel et al. 2017). Dragonflies attract public attention because of their striking range of coloration and body size, and ease in which they are observed in nature, making them a flagship species for aquatic environments (Marco \& Viana 2005, Miguel et al. 2017). Additionally, they have importance as bioindicators, due to their environmental sensitivity (Clausnitzer et al. 2009, Oliveira-Junior et al. 2015, Carvalho et al. 2018, Oliveira Júnior \& Juen 2019).

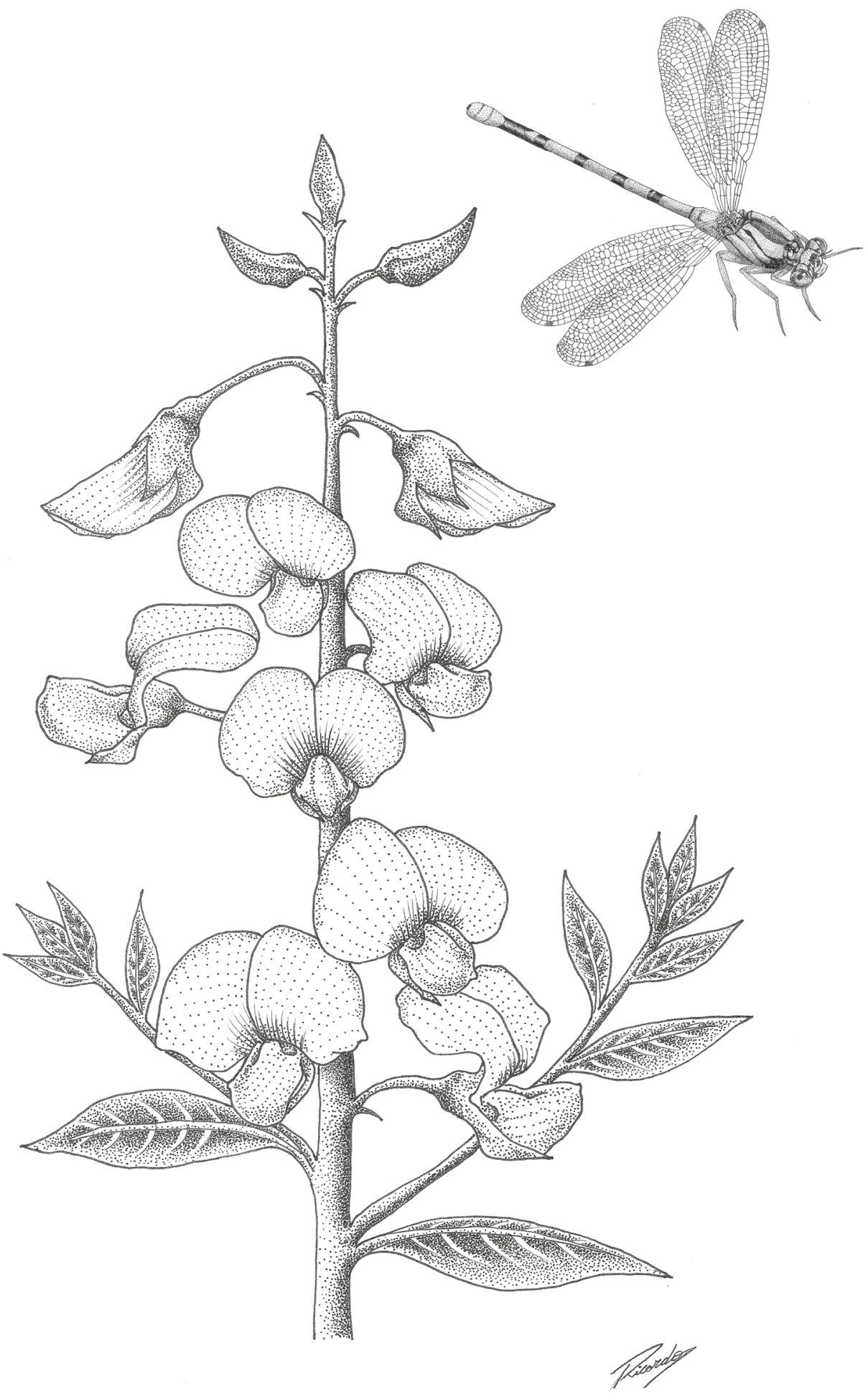

Figure 1. Illustration of a damselfly from the genera Argia spp. (Zygoptera) and one individual of Crotalaria genera (Crotalaria junceae) (Image: Ricardo Ribeiro da Silva). 
The life cycle of Odonata comprises two stages, which have different ecophysiological requirements: the larval stage, which is strictly aquatic (mainly dependent on water conditions) and comparatively long in duration; and the adult stage, during which winged adults, that have a short lifetime, keep a close relationship with the vegetation surrounding aquatic environments (Stoks \& Córdoba-Aguillar 2011, Mendes et al. 2017). Both life stages are voracious generalist predators, consuming a great variety of prey items, including small organisms such as other arthropods, tadpoles, and fishes (Corbet 1999). Nevertheless, larvae and adults do not occupy the same ecological niche, and thus, they do not use the same resources. Therefore, different strategies exist between life stages of Odonata in the methods deployed to search for and capture prey.

Over evolutionary history, larvae have developed strategies to increase predation success, such as the use of camouflage. Adults, on the other hand, feed on flying insects they can catch during flight but is some situation they can prey other types of organisms (Fincke 1984). Accordingly, vision plays an important role in the predation success of dragonflies. In fact, odonates have one of the most advanced visual systems in the animal kingdom, and it is known that most dragonflies can see ultraviolet light, and because of this they are able to see across four spectral sensitivities (Harris et al. 2011). Moreover, their highly developed visual system plays an important role in other aspects of dragonfly behavior, such as finding mates, oviposition site selection, and the avoidance of predators (Corbet 1999, Harris et al. 2011). Due to their complex vision, they are excellent predators, for example, some species of the genera Mecistogaster can remove insects trapped in spider webs (Fincke 1984). Some dragonfly species also appear to use olfactory systems (e.g. Libellula species) to detect prey species, but most taxa cannot detect smells or be attracted to aromatic substances (Suhling et al. 2014). There is a great amount of evidence that indicates dragonflies and damselflies could use the olfactory cues to detect preys too (Suhling et al. 2014; Piersanti et al. 2014).

\section{Control of disease vectors}

Based on their predatory success, in fields like medicine and agriculture, some insects are used to control other insects populations, which are considered in some situations as pests in some cases (Nam et al. 2000, Yaser et al. 2010), and even to control the spreading of non-native plant species (Room et al. 1981, Sheppard et al. 2003). In medicine, some studies use biological agents to control human diseases (Acquah-Lamptey \& Brandl 2018), and in ecology, these agents are often used to control populations of 'problematic' species (e.g. crop pests or invasive species). In fact, dragonfly larvae have shown a great capacity and efficiency as biological control agents of mosquito larvae (Fincke et al. 1997, Andrade 2011, Quiroz- Martínez \& Rodríguez-Castro 2007, Roberts 2012, Venkatesh \& Tyagi 2015). Among global regions, tropical areas stand out due to the high number of medically significant insect-borne diseases, for example, dengue, malaria, chikungunya and zika virus, which are all transmitted by culicid mosquito. Most government actions include the use of chemical controls (e.g. insecticides) to eliminate vectors; other actions encompass the elimination of breeding habitats (WHO 2019). For both dengue virus and malaria, the adult females of the vector species require clean water to lay their eggs, a necessary condition for larval until they reach the adult stage (WHO 2019).

\section{The Crotalaria fallacy}

In Brazil, problems with neglected tropical diseases, together with zika virus, are very common and remain key public health concerns among both policymakers and medical authorities (Ministério da Saúde do Brasil 2019). The main challenge for authorities is to make the importance of avoiding the creation of suitable habitats for vectors clear (Ministério da Saúde do Brasil 2019, WHO 2019). One controversial act promoted by some communities and local policymakers are to use the Crotalaria spp. (a genus of Leguminosae family) (Figure 1) to attract natural predators of the vectors, such as dragonflies (Kuster 2010, Matos \& Vaz 2017). The main goal is to reduce vector populations, and thus the number of people infected by insect-borne diseases. According to proponents of this method, the presence of Crotalaria spp. attracts adult dragonflies; thereafter the females would lay their eggs in the water, near to these plants; and the larvae predate the mosquito larvae, thus reducing adult emergence of the vector.

However, there is no scientific evidence that Crotalaria spp. attracts dragonflies, when the former is present in the environment (Wutke et al. 2015). We found just the article from Murugan et al. (2015) that conducted an experiment using nanoparticles obtained from Crotalaria verrucosa L (Linnaeus, 1753). The aim of the study was to evaluate if the presence Crotalaria's compounds could enhance the predation rates of dragonflies on mosquitoes from Culicidae. The results indicated that after nanoparticles compounds were used, predation rates of dragonfly larvae on culicidians increased (Murugan et al. 2015). Although that study was rigorously conducted, following all steps established by the scientific method (different from the movements occurring in Brazil) and the authors highlighted that additional studies are necessary for more conclusions.

Most species of Crotalaria spp. are perennial shrubs native to the Neotropical region and are considered exotic in several countries where they have been introduced (Polhill 1982, Vieira and Pessoa 2001). Therefore, the use of these plants to control vector populations, without any solid evidence of their effectiveness as a means to promote vector control, can cause unnecessary ecological damage to the environment, and also for agriculture and livestock (Keane and Crawley 2002, Pyšek \& Richardson 2010, Andrade 2011). According to our research, this myth began around 2010 and, unfortunately, has been perpetuated so far. More worrying is that the seeds have been distributed in the state of Pará, in the Amazon, so it is strong evidence that Crotalaria spp. it has a high potential risk of invading protected areas in Brazil, such as the Amazon rainforest (Fonseca et al. 2006), as well as dispersing in some areas of the Cerrado biome (Fernandes et al. 2015).

In spite of the reasons presented by government representatives supporting the use of Crotalaria, there is no evidence of any strong ecological relationship between dragonflies and Crotalaria species. It means that some officials may think they are helping the local population but in fact, they are spending public money on something that will not solve the dengue problem. As previously discussed, dragonflies have highly developed visual systems, and any shiny surface gets their attention, mostly because of their behaviors, including foraging and reproductive ones, occurring on or surroundings of aquatic environments (Corbet 1999, Stevani et al. 2000). These places (e.g. ponds, rivers, streams) have shiny surfaces, which do reflect the sunlight, for this way the dragonflies are attracted by them. 
Additionally, the attractiveness of the dragonflies to shiny surfaces is so strong that several studies (Stevani et al. 2000, Wildermuth \& Horvéth 2005, Kriska et al. 2006) already found female dragonflies laying their eggs on car bonnets, and the reason being is that the metallic surfaces reflect sunlight in a similar way to aquatic surfaces.

Additionally, there is another way to explain this possible relationship without considering a causal link: the dragonflies are territorial individuals, where the male need physical habitat structures, such as branches and foliage, to defend oviposition resources and to catch prey (Corbet 1999, Remsburg \& Turner 2009). If some water body has an individual of Crotalaria nearby, a type of biotic component that will provide these kinds of physical structures, then male dragonflies will use it as a perch. In other words, dragonflies may use any suitable plant (Crotalaria or other species) close to the water as a perch, hence, there is no reasonable argument to promote this specific plant species.

\section{Concluding remarks}

One of the greatest possibilities to explain why some people think that these plants would attract the dragonflies might be an anecdotal experience: Unwittingly, someone might have been seen a dragonfly perching on a Crotalaria plant and thought that there was some strong ecological factor underpinning this interaction.

However, no one has subsequently performed a study to test if this fact really happens in nature using the scientific method. Web searches of academic and non-academic databases showed very little published information about this, with much of the material being found in the grey literature, such as government reports, religious folders, videos, conferences, symposium proceedings, opinions in blogs and other nonpeer- reviewed sources (Figure 2) (see also Supplementary Material 1).

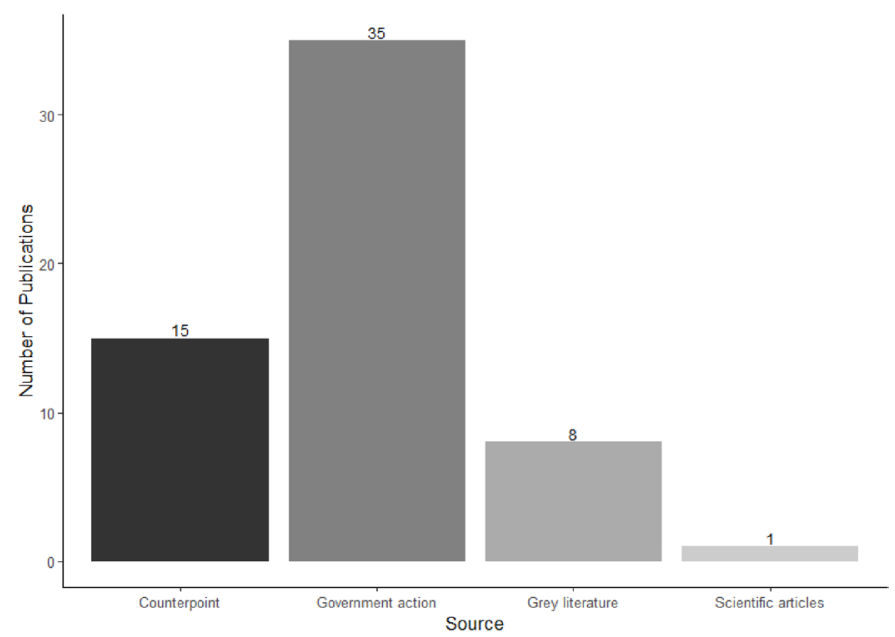

Figure 2. Histogram with the types of material found on the internet about the relationship between Crotalaria and dragonflies and damselflies; Counterpoint: considers any information that did not support the Crotalaria use, from symposiums or blogs; Government actions: encompass actions taken by local policymakers from their official media; Grey literature: considers material from symposiums, meetings, or information of blogs; Scientific articles: consider studies about dragonflies, Crotalaria and insect-borne diseases following the scientific method.
Therefore, there is no clear scientific evidence on the use of Crotalaria spp. to control for insect-borne diseases. This is a dangerous way to use a biological control agent because other scientific studies (i.e. surveys that used some organisms to eliminate pests) were carefully performed before introducing an organism, especially an exotic species like Crotalaria spp. Additionally, these misuse of biological control in a great number of Brazilian municipalities became widespread, occurring in all regions (Figure 3), indicating at least a non-use of scientific guidelines (Supplementary Material 2). Thus, it should be better let clearer for governments and communitarian leaders that, without the use of validated methods through scientific method, it's dangerous to grow a great number of non-native plant species in the cities.

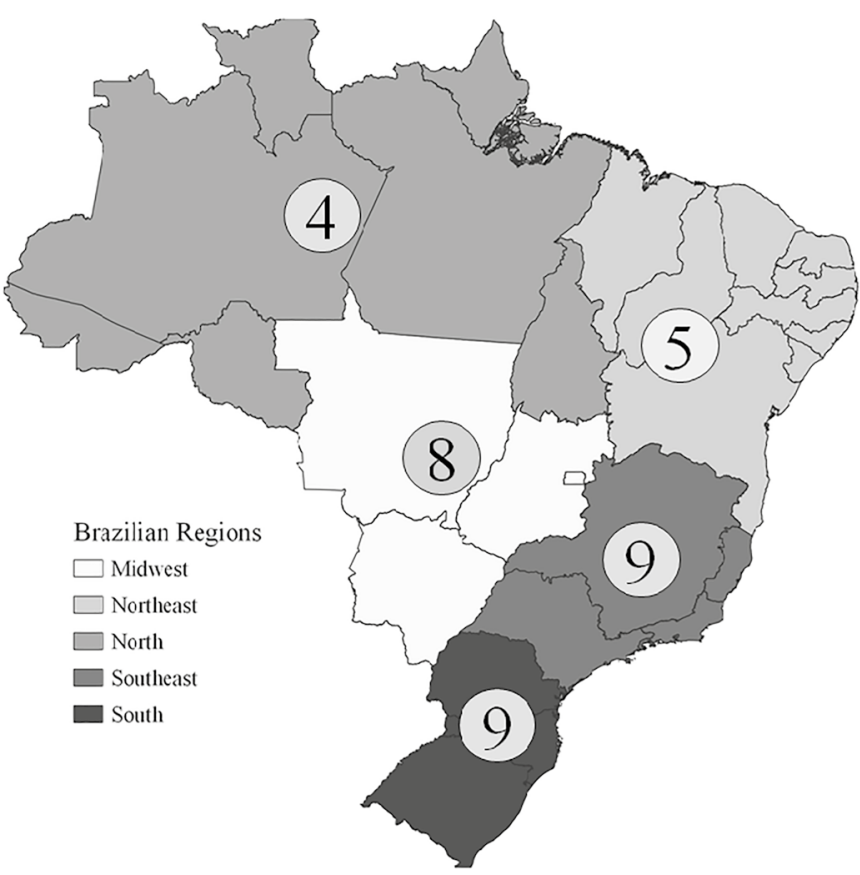

Figure 3. The spread and number of Crotalaria used in whole Brazilian regions. The information was taken from official media of local governments, supporting the use of this plant against the insect-borne diseases.

Finally, the main problem is the purposeful spread of Crotalaria, with the damage going beyond an ecological disturbance of natural environments or agriculture. The use of Crotalaria becomes a profitable market, where people sell the seeds to environmental agencies or even directly to local communities, just to make a quick profit on the lack of scientific clarity on this matter. Thus, as scientists, we need to do more disseminate accurate and reliable information about this subject, in order to convince policymakers, and influential people within society (e.g. religious leaders) to use academic studies such as ours to help solve environmental and public health problems. The best way to eliminate diseases such as dengue, malaria, and zika is to prevent containers with standing water in urban areas, and this information is already freely available in the public domain. With this act, we hope to promote the spread of evidence-based approaches for controlling insect-borne diseases. 
There are no funders to report for this submission.

\section{Supplementary material}

The following online material is available for this article:

Material 1 - Counterpoint

Material 2 - Electronic Adress Local

\section{Acknowledgements}

This study was financed by Conselho Nacional de Desenvolvimento Científico e Tecnológico - CNPq (processes: 433125/2018-7 and 428961/2018-5) and the Coordenação de Aperfeiçoamento de Pessoal de Nível Superior - Brasil (CAPES) - Finance Code 001. We acknowledge CAPES and CNPq for granting scholarship and productivity grant to NLF, CCM and LJ (process \#307597/2016-4). We are also grateful to BRC (Brazilian Research Consortium - this paper is number 0005 in the publication series of the BRC) and Hydro Alunorte company for providing scholarship to JSB and FASN. The authors are grateful to Dr. Alistair John Campbell for English's revising the text and for the review/suggestions from two anonymous reviewers. We are also thankful to MSc. Ricardo Ribeiro da Silva to draw the figure 01 .

\section{Author contributions}

Joás da Silva Brito: Contribution to concept and design of the study, in manuscript preparation; Contribution to critical revision.

Nayara Louback-Franco: Contribution to manuscript preparation; Contribution to critical revision.

Cristian Camilo Mendoza: Contribution to manuscript preparation; Contribution to critical revision.

Flávia Alessandra da Silva Nonato: Contribution to manuscript preparation; Contribution to critical revision.

Leandro Juen: Conceptualization, supervised and designed the study and wrote the manuscript.

Thaísa Sala Michelan: Conceptualization, supervised and designed the study and wrote the manuscript.

All authors edited the manuscript and approved the submitted version.

\section{Conflicts of interest}

"The author(s) declare(s) that they have no conflict of interest related to the publication of this manuscript".

The corresponding author informed all authors about the journal's publishing policy.

\section{References}

ACQUAH-LAMPTEY, D. \& BRANDL, R. 2018. Effect of a dragonfly (Bradinopyga strachani Kirby, 1900) on the density of mosquito larvae in a field experiment using mesocosms. Web Ecol. 18(1):81-89.

ANDRADE, C.F.S. (2011) Aedes aegypti control - what to update in a subject with traditional solutions? 7th International Conference on Urban Pests Ouro Preto, Brazil. https://www.researchgate.net/publication/275567865.

CARVALHO, F.G., DE OLIVEIRA ROQUE, F., BARBOSA, L., DE ASSIS MONTAG, L.F. \& JUEN, L. 2018. Oil palm plantation is not a suitable environment for most forest specialist species of Odonata in Amazonia. Anim. Conserv. 21(6):526-533.
CLAUSNITZER, V., KALKMAN, V.J., RAM, M., COLLEN, B., BAILLIE, J.E.M., BEDJANIČ, M., DARWALL, W.R.T., DIJKSTRA, K.D.B., DOW, R., HAWKING, J., KARUBE, H., MALIKOVA, E., PAULSON, D., SCHÜTTE, K., SUHLING, F., VILLANUEVA, R.J., VON ELLENRIEDER, N. \& WILSON, K. 2009. Odonata enter the biodiversity crisis debate: The first global assessment of an insect group. Biol. Conserv. 142(8):1864-1869.

CORBET P.S. 1999. Dragonflies: Behavior and Ecology of Odonata. Comstock Publisher Association, Ithaca, NY.

FERNANDES, G.W., SANTOS, R., BARBOSA, N.P.U., ALMEIDA, H.A., CARVALHO, V. \& ANGRISANO, P. 2015. Ocorrência de plantas não nativas e exóticas em áreas restauradas de campos rupestres. Planta Daninha 33(3):463-482.

FINCKE, O.M. 1984. Giant damselflies in a tropical forest: reproductive biology of Megaloprepus coerolatus with notes on Mecistogaster (Zygoptera; Pseudoestigmatidae). Adv. Odonatol. 2: 13-1.

FINCKE, O.M., YANOVIAK, S.P. \& HANSCHU, R.D. 1997. Predation by odonates depresses mosquito abundance in water-filled tree holes in Panama. Oecologia 112(2):244-253.

FONSECA, R.L., GUIMARÃES, P.R., MORBIOLO, S.R., SCACHETTIPEREIRA, R. \& PETERSON, A.T. 2006. Predicting invasive potential of smooth crotalaria (Crotalaria pallida) in Brazilian national parks based on African records. Weed Sci. 54(3):458-463.

HARRIS, W.E., FORMAN, D.W., BATTELL, R.D., BATTELL, M.T.R., NELSON, A.K. \& BRAIN, P.F. 2011. Odonata colour: More than meets the eye? Int. J. Odonatol. 14(3):281-289.

KEANE, R.M. \& CRAWLEY, M.J. 2002. Exotic plant invasions and the enemy release hypothesis. Trends Ecol. Evol. 17(4):164-170.

KRISKA, G., CSABAI, Z., BODA, P., MALIK, P. \& HORVÁT, G. 2006. Why do red and dark-coloured cars lure aquatic insects? The attraction of water insects to car paintwork explained by reflection polarization signals. Proc. R. Soc. B Biol. Sci. 273(1594):1667-1671.

KUSTER, A. 2010. Agroecologia: Manejo de pragas e doenças. Available on www.agroecologia.inf.br.

MATTOS, E.C.A \& VAZ, T.R.D. 2017. Políticas Públicas e Educação: combate ao Aedes Aegypti no Município de Naviraí-MS. In: I Encontro Internacional de Gestão, Desenvolvimento e Inovação.

MARCO, P. \& VIANNA, D.M. 2005. Distribuição do esforço de coleta de Odonata no Brasil - Subsídios para escolha de áreas prioritárias para levantamentos faunísticos. Lundiana 6(SUPPL.):13-26.

MENDES, T.P., OLIVEIRA-JUNIOR, J.M.B., CABETTE, H.S.R., BATISTA, J.D., JUEN, L. Congruence and the biomonitoring of aquatic ecosystems: are odonate larvae or adults the most effective for the evaluation of impacts? Neotrop. Entomol. 6: 631-641.

MIGUEL, T.B., CALVÃO, L.B., VITAL, M.V.C. \& JUEN, L. 2017. A scientometric study of the order Odonata with special attention to Brazil. Int. J. Odonatol. 20(1):27-42.

MINISTÉRIO DA SAÚDE (2019). http://www.saude.gov.br/component/tags/ tag/dengue. (Last access in 03/12/2019)

MITTERBOECK, T. F. \& ADAMOWICZ, S.J. 2013. Flight Loss Linked to Faster Molecular Evolution in Insects. Proc. R. Soc. B. 280: 20131128.

NAM, V.S., YEN, N.T., HOLYNSKA, M., REID, J.W. \& KAY, B.H. 2000. National progress in dengue vector control in Vietnam: Survey for Mesocyclops (Copepoda), Micronecta (Corixidae), and fish as biological control agents. Am. J. Trop. Med. Hyg. 62(1):5-10.

OLIVEIRA-JUNIOR, J.M.B. \& JUEN, L. 2019. The Zygoptera/Anisoptera ratio (Insecta: Odonata): a new tool for habitat alterations assessment in Amazonian streams. Neotrop. Entomol. 48(4):552-560.

OLIVEIRA-JUNIOR, J.M.B., SHIMANO, Y., GARDNER, T.A., HUGHES, R.M., DE MARCO JÚNIOR, P. \& JUEN, L. 2015. Neotropical dragonflies (Insecta: Odonata) as indicators of ecological condition of small streams in the eastern Amazon. Austral Ecol. 40(6):733-744.

PIERSANTI, S., FRATI, F., CONTI, F., REBORA, M. \& SALERMO, G. 2014. The sense of smell in Odonata: An electrophysiological screening. J. Ins. Phys. 70: 49-58. 
POLHILL, R.M. 1982. Crotalaria in Africa and Madagascar. Rotterdam, The Netherlands: Balkema.

QUIROZ-MARTÍNEZ, H., \& RODRÍGUEZ-CASTRO, A. 2007. Aquatic insects as predators of mosquito larvae. J. Am. Mosquito Contr. Assoc. 23(sp2), 110-117.

REMSBURG, A.J. \& TURNER, M.G. 2009. Aquatic and terrestrial drivers of dragonfly (Odonata) assemblages within and among north-temperate lakes. J. North Am. Benthol. Soc. 28(1):44-56.

ROBERTS, D. 2012. Responses of three species of mosquito larvae to the presence of predatory dragonfly and damselfly larvae. Entomol. Exp. Appl. 145(1):23-29.

PYŠEK, P. \& RICHARDSON, D.M. 2010. Invasive species, environmental change and management, and health. Annu. Rev. Env. Res. 35(1):25-55.

ROOM, P.M., HARLEY, K.L.S., FORNO, I.W. \& SANDS, D.P.A. 1981. Successful biological control of the floating weed Salvinia. Nature 294(9):1689-1699.

SHEPPARD, A.W., HILL, R., DECLERCK-FLOATE, R.A., OLCKERS, T., JR., P.C.Q. \&

ZIMMERMANN, H.G. 2003. A global review of risk-benefit-cost analysis for the introduction of classical biological control agents against weeds: a crisis in the making? Biocontrol News Inf. 24(4):91N-108N.

STEVANI, C. V., DE FARIA, D.L.A., PORTO, J.S., TRINDADE, D.J. \& BECHARA, E.J.H. 2000. Mechanism of automotive clearcoat damage by dragonfly eggs investigated by surface enhanced Raman scattering. Polym. Degrad. Stab. 68(1):61-66.

STOKS, R. \& CÓRDOBA-AGUILAR, A. 2012. Evolutionary ecology of Odonata: a complex life cycle perspective. Annu. Rev. Entomol. 57(1):249-265.
SUHLING F., SAHLÉN G., GORB S., KALKMAN V.J., KLAAS-DOUWE D. B., VAN-TOL J. 2014. Order Odonata, p. 893-932. In: Ecology and General Biology: Thorp and Covich's Freshwater Invertebrates (eds). p. 1148.

VENKATESH, A. \& TYAGI, B.K. 2015. Bradinopyga geminata (Anisoptera: Libellulidae) as a predator of Aedes aegypti immatures (Diptera: Culicidae). Int. J. Mosq. Res. 2(3):98-105.

VIEIRA, C.M. \& PESSOA, S. de V.A. 2001. Estrutura e composição florística do estrato

herbáceo-subarbustivo de um pasto abandonado na Reserva Biológica de Poço das Antas, município de Silva Jardim, RJ. Rodriguésia 52(80):17-30.

WILDERMUTH, H. \& HORVÁTH, G. 2005. Visual deception of a male Libellula depressa by the shiny surface of a parked car (Odonata: Libellulidae). Int. J. Odonatol. 8(1):97-105.

WHO - World Health Organization. 2019. Dengue and severe dengue. Retrieved from https://www.who.int/news-room/fact-sheets/detail/dengue-and-severe-dengue.

WUTKE E.B., AMBROSANO E.J., CALEGARI A., WILDNER L.P., MIRANDA M.A.C. 2015. Aedes aegypti: controle pelas crotalárias não tem comprovação científica. Campinas: Instituto Agronômico, 16 p; Documentos IAC, 114 - online http://www.iac.sp.gov.br/publicacoes/publicacoes_online/ pdf/documentos_iac_114.pdf

YASER, S.A., VATANDOOST, H., YAVAR, R., REZA, A.M., REZA, S.D.A. \& AZIM, P. 2010. Evaluation of biological control agents for mosquitoes control in artificial breeding places. Asian Pac. J. Trop. Med. 3(4):276-277.

Received: $18 / 10 / 2019$

Revised: 20/12/2019

Accepted: 20/01/2020

Published online: 30/03/2020 